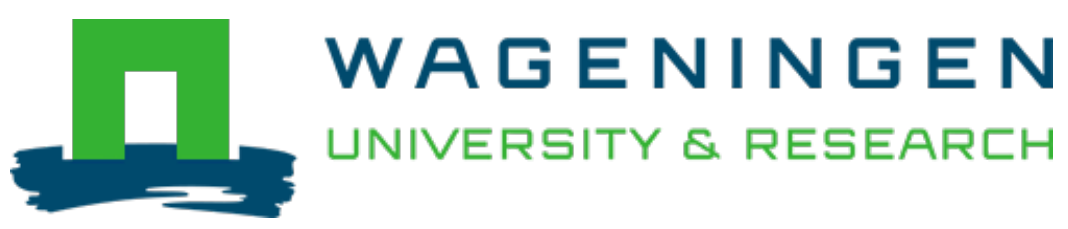

\title{
Choice of technology in food processing for rural development
}

Rural households in emerging societies: technology and change in sub-Saharan Africa

Bruinsma, D.; Nout, M.J.R.

https://doi.org/10.4324/9781003135098-13

This publication is made publicly available in the institutional repository of Wageningen University and Research, under the terms of article $25 \mathrm{fa}$ of the Dutch Copyright Act, also known as the Amendment Taverne. This has been done with explicit consent by the author.

Article $25 \mathrm{fa}$ states that the author of a short scientific work funded either wholly or partially by Dutch public funds is entitled to make that work publicly available for no consideration following a reasonable period of time after the work was first published, provided that clear reference is made to the source of the first publication of the work.

This publication is distributed under The Association of Universities in the Netherlands (VSNU) 'Article $25 \mathrm{fa}$ implementation' project. In this project research outputs of researchers employed by Dutch Universities that comply with the legal requirements of Article $25 \mathrm{fa}$ of the Dutch Copyright Act are distributed online and free of cost or other barriers in institutional repositories. Research outputs are distributed six months after their first online publication in the original published version and with proper attribution to the source of the original publication.

You are permitted to download and use the publication for personal purposes. All rights remain with the author(s) and / or copyright owner(s) of this work. Any use of the publication or parts of it other than authorised under article $25 \mathrm{fa}$ of the Dutch Copyright act is prohibited. Wageningen University \& Research and the author(s) of this publication shall not be held responsible or liable for any damages resulting from your (re)use of this publication.

For questions regarding the public availability of this publication please contact openscience.library@wur.nl 


\section{Choice of Technology in Food Processing for Rural Development}

\section{Domien Bruinsma and Robert Nout}

\section{Developments in Food Processing}

People have always endeavoured to process food products; to make them edible, to preserve them and avoid losses, to extract certain valuable components, to produce composite products of improved nutritional or organoleptic quality, or to generate income and employment. In addition to the existing, traditional methods of food processing, industrial processing has been introduced in subSaharan Africa during the last decades. Often this has had important effects on rural areas. Due to the introduction of large-scale production on estates and processing of palm oil and sugar, many people were displaced from their land. At the same time, these plantations and industries created new employment opportunities, though not always in sufficient quantities to employ all the landless. This chapter examines both the potential and the pitfalls of smallscale, rural, food-processing industries. Cash-crops are not included for two reasons: first, the processing of these crops is determined more by export than by local requirements, and options are therefore often quite restricted; and second, the processes themselves are well understood.

Medium- and large-scale agro-industries had various indirect

influences on rural development, especially those that were created to process local raw materials, which did not need to be grown on estates. These factories created a demand for certain raw materials and encouraged farmers to produce more cash-crops. Sometimes this reduced their available hectarage and time for food production. Although most of these agro-industries produced for the export market in the first instance, their production was often also intended for the local market and as such competed with traditionally processed food products. The medium- and large-scale food 
industry in Africa is now to a large extent producing for the local market. Presently, this industry is encountering various problems stemming from its 'technical' characteristics, including excess capacity, lack of spare parts and lack of adequately trained personnel, in addition to its social impact. The firms tend to disrupt the existing rural social structure by displacing female labour, introducing market relations between producer, manufacturer and consumer, and changing the ownership distribution of the means of production.

These problems have stimulated the interest of various organisations in the development of 'appropriate technology' in two directions. The first can be grouped under the heading of improving or upgrading existing processes or products in medium-scale foodprocessing industries. The second direction is related to household production (often by women) with the same purposes. Examples of both are given below. Special attention is paid to the social implications of those technologies that imply a shift (of at least some parts of the processing cycle) from household production to the more formal production at a larger scale.

Although there is no universally accepted definition of 'appropriate technology', and different authors emphasise different aspects of appropriateness, there appears to be broad agreement as to the main focal points, notably, the use of labour, the extent of investment, the degree of sophistication, the scale of production and awareness of the needs of the target group. The range of traditional foodprocessing industries at the village level is vast. But if so much is going on already, what can development agencies do and, perhaps more important, why should they get involved if it is already done quite well? A second and equally important question is: What can be done? The answer is, technically, just about anything. But there are many other factors (e.g. political, social, cultural) which can severely inhibit freedom of action. It must be realised that a piece of machinery can only be appropriate if both time and place are right. If the setting changes, or the equipment is operated in a different environment, its characteristics may no longer be appropriate.

A number of small-scale food-processing technologies have been developed during the last twenty years. The following examples are illustrative; they describe the technology, and its nutritional, technical and socio-economic advantages, as compared to traditional processing. Where possible, some assessment of the impact of the technology (both intended and unintended) and the causes of that impact are also given.

\section{Cereal Processing}

In the field of cereal processing, flour milling technology and manufacture of weaning food formulas will be discussed with particular reference to the scale of operations and the choice of processes, respectively.

\section{Flour Milling}

The scale of operations in rural flour milling has nutritional and quality, as well as economic and social, implications. Locallygrown cereals in sub-Saharan Africa include maize, rice, sorghum (guinea corn) and various types of millets. Traditionally, these are consumed as cooked doughs, pancakes, fritters, gruels (watery porridges) and beers. In many regions, cereals are soured by natural fermentation prior to cooking. The resulting characteristic sour taste is popular, and it is a common belief that fermented cereal products are more nutritious than non-fermented cereal products.

Flour is traditionally prepared by the labour-intensive process of manual pounding with pestle and mortar, combined with winnowing to remove the fibrous parts (testa), especially of millets and sorghum. On average, $25 \mathrm{~kg}$ of raw material could be processed daily per mortar, serving the needs of 25-35 consumers (Table 11.1). This home-scale technique has the advantages of low investment, short distribution distance and flexibility.

In addition, it is suitable for processing the entire range of available cereals. However, the task of pounding requires considerable time and therefore competes with other productive activities. Consequently, the demand for more convenient flour milling methods has resulted in the gradual introduction of the phenomenon of the service mill (Table 11.1), preceded in some areas by hand-operated maize mills. A typical village service mill consists of a 'disc' or 'plate' mill (e.g. the 'Premier Mill'), commonly driven by a $2-5 \mathrm{hp}$ diesel (e.g. 'Lister') or electric engine. Payment for such custom milling is either in cash or in kind. A recent survey in Cotonou (Benin) illustrates the widespread use of the relatively small-scale technology. In this town of 420,000 inhabitants, 650 service mills are in operation with an average individual daily throughput of 215 $\mathrm{kg}$ (mainly of maize). Likewise, it was estimated that in Niger, in 1982, more than 1,500 service mills were in use. The widespread adoption of this technology may be due to the fact that it meets a basic felt need at an acceptable cost; that is, that the benefits (time 
Table 11.1 Small-scale flour milling technologies

\begin{tabular}{lccc}
\hline \hline Technology & Scale & $\begin{array}{c}\text { Throughput } \\
(\mathrm{kg} / \text { day) }\end{array}$ & $\begin{array}{c}\text { Consumers served } \\
\text { (number/day) }\end{array}$ \\
\hline $\begin{array}{l}\text { Pounding } \\
\text { (mortal and pestle) }\end{array}$ & Home-Quarter & $\approx 25$ & $25-35$ \\
$\begin{array}{l}\text { Service mill } \\
\text { (disc or plate mill) }\end{array}$ & Quarter-Village & $200-300$ & $250-500$ \\
$\begin{array}{l}\text { IDRC-RIIC } \\
\text { (dehuller and } \\
\text { hammer-mill) }\end{array}$ & Village-Town & $2,000-4,000$ & $5,000-10,000$ \\
\hline \hline
\end{tabular}

and energy saved) exceed the costs (payment for service milling, distance to the mill).

Small hammer mills, however, are not immune to the problems experienced by medium- and large-scale processors. In the Equatoria region of the Sudan mechanical diesel mills stand idle because of irregular supplies of diesel, the frequent need for repairs, lack of spare parts and management difficulties (Ballot, 1985). Women's co-operatives are proposed as a management solution, and efforts have been initiated by a women's self-help project funded by the German federal government, but are constrained by the lack of traditional co-operation mechanisms between women. Both gender and ownership issues affect, and are affected by, the introduction and choice of scale of food-processing technology. In Senegal diesel mills operate efficiently and profitably in the larger and/or more prosperous villages, but the remaining poorer and/or smaller villages with smaller quantities of raw material to process may be more appropriately served by an animal traction mill because of its smaller scale and lower capital and operating costs. The women could bring their own donkeys to provide the animal draught power. A niche frequently exists for businesses of various scales using different technologies in different parts of the same country (Hyman, 1989). However, whereas animal dfaught power is a traditional technology in Asia, in some parts of sub-Saharan Africa it is not, so its appropriateness in a particular situation would have to be evaluated in the same way as that of any other introduced technology.

The quality of the products processed by these village mills is crude, since the entire cereal grain is ground without separation of the fibrous seed coat. This need not be a disadvantage when maize is milled since its weight fraction of seed coat is relatively small. In fact, whole maize meal tends to be more nutritious because of the oil and vitamin content of the maize germ it contains. On the other hand, sorghum and millets have a much larger proportion of seed coat containing indigestible fibres, tannins and pigments. When ground to a meal in a single disc-mill, they yield unacceptable flours. The production of sorghum and millets represents approximately 20-25 per cent of the total African cereal crop. There is a tendency to regard them as 'poor man's crops', since they are mainly processed and consumed on a domestic scale in the rural areas. Sorghum and millet are better suited to semi-arid conditions than maize, and the growing of a diversified cereal crop which includes them may be of strategic importance to national food security, as well as contributing to development objectives that favour the rural population. The growing consumer demand for imported grains and flours (rice, wheat and maize) is unsustainable (Delgado and Miller, 1985). During the 1970s, efforts were made to promote the growing of more sorghum and millets, and to introduce high-yielding and bird-resistant new varieties. However, there was no incentive for farmers to produce more than the subsistence level, mainly because urban service mills were unable to process surplus sorghum or millet into acceptable consumer products. Furthermore, with the expansion of maize mills into marginal areas, better suited to millet and sorghum production (e.g. parts of eastern Kenya and northern Zambia), women have experienced an inducement to shift both crop production and consumption towards this less appropriate crop, for which hand-pounding is no longer necessary. Development of domestic or village-scale sorghum and millet dehullers could help to contain this trend (Cf. Haswell herein).

The creation of an urban market for surplus sorghum and millets was made possible by the introduction of a technology developed in response to the needs of rural women to reduce the time spent in food preparation and processing. A new system for small-scale dehulling or decorticating and flour milling was developed by the IDRC (International Development and Research Centre, Canada). The basic design of the dehuller (Figure 11.1) consists of a metal shaft on which a number of grinding stones are evenly spaced about $2 \mathrm{~cm}$ apart. This rotor is enclosed by a barrel which is partly filled with grain. The discs run at 1,500-2,000 rpm and gradually wear off the outer layers of the grain. (Legumes can be processed too.) Subsequently, the dehulled grains are ground to flour using a hammer-mill. Several prototypes were tested: the early Botswanamade 'RIIC' (Rural Industries Innovation Centre) dehuller performed only on a continuous flow basis, and could not deal with 
Figure 11.1 The basic design of the dehuller

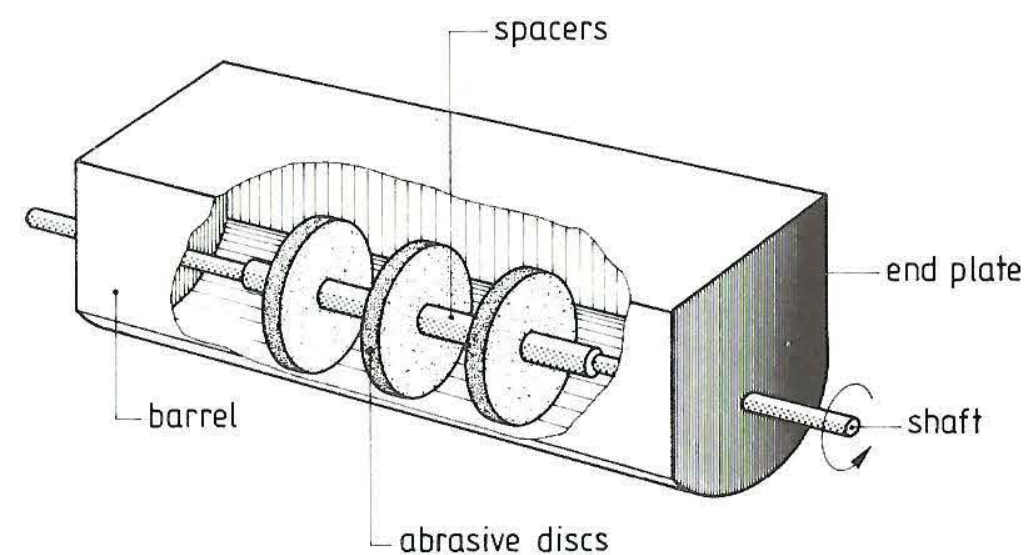

small batches being brought by individuals who were seeking a milling service for 'their' sorghum. A needs reassessment led to successful modification. The scale and capacity of the RIIC dehuller, while appropriate to Botswana where 80 per cent of the population live in large villages, was reduced to fit better the sparser settlement patterns in The Gambia and Zimbabwe (Schmidt, 1988). Thus, considerations of capacity utilisation, distance of users from the 'service', and settlement pattern influenced the appropriate scale of the dehuller and adapted versions have been locally produced and are operational in Botswana (37 in use in 1987), The Gambia (13 in use in 1987) and Zimbabwe ( 40 foreseen in 1990). The present RIIC dehuller can handle batches as small as 5 $\mathrm{kg}$ and, in continuous flow operation, can process 5 tonnes per 8-hour shift. The economical breakeven point lies around 1.5-2 tonnes per day. From Table 11.1 it can be seen that this scale of operation can only be profitable under semi-urban conditions, considering the throughput, cost of distribution and the fact that it produces a product (sorghum and millet flour) which has to compete with the usual staple (maize or rootcrops)

The IDRC experience was summarised by Schmidt (1987) as follows:

1 Economies of scale apply to the marketing and distribution of the processed product, but not to the processing itself.

2 Investments were not as profitable as expected because of heavy competition between mills and oversupply of installations.
3 Credit agencies had not anticipated occasional droughts and consequent reduced throughput.

Nevertheless, machine dehulling would merit a prominent place in African cereal processing, since:

1 It frees woman and child labour for other tasks.

2 It successfully handles high tannin (bird-resistant) cultivars of sorghums and millets.

3 It helps to generate urban demand for sustained surplus production.

In Botswana despite efforts to direct the technical capability of the dehuller towards rural beneficiaries, and to steer the dissemination of the technology towards group investors such as cooperatives and development trusts, rather than individuals, little progress was made towards the achievement of either of the development objectives - rural job creation or a decentralised milling industry. The nature of the industry's evolution, which was influenced by an ambiguous policy environment and critical raw materials shortage caused by drought, may have caused a permanent change in the way sorghum is processed; commercial milling has almost completely displaced service milling (Schmidt, 1988). No attempt has been made to evaluate the impact of the ownership distribution of the dehuller technology, though other studies indicate that ownership and control of food processing technology may be a key factor determining its sustainability and differential impact (ILO, Geneva, 1984; Hyman, 1989).

\section{Weaning Food Manufacture}

Weaning foods are used to feed infants of 6-24 months, especially when breastfeeding needs to be supplemented, but children are still too young to eat the family diet. In urban and rural situations, a growing demand for convenient weaning food has developed for similar reasons as outlined for cereal flours. In addition, the specific nutritional needs of small children are often not met by the traditional porridges based on staples such as maize or cassava. Protein-Energy-Malnutrition (PEM) and watery diarrhoea contribute significantly to the prevailing high infant mortality rate. Adequate weaning foods must therefore supply sufficient energy (4.2 kJoule per gram of porridge) and protein (8 per cent net protein utilisation), and must be microbiologically safe. 
Using locally available and acceptable ingredients, it is possible to meet these requirements by mixing staples (cereals or rootcrops) with high-protein ingredients (beans or other legumes). Sufficient 'energy-density' can be obtained with oil (expensive), sugar or malt (germinated cereal). In most African countries, market prices for cereals and legumes fluctuate widely according to season and availability. If we define the prices immediately after harvest as 'Ici' (lowest cost of ingredients), it is not unusual that home-prepared weaning food costs 2-3 $\times$ lci. This is in sharp contrast to the price of weaning formulae imported from Europe or manufactured by local large-scale industries under foreign licence. Such products cost 10-25 × lci, and can only be afforded by consumers from the middle and higher-income brackets.

The Royal Tropical Institute of Amsterdam (KIT) is assisting in the establishment of rural, small-scale weaning food factories in African countries, including Burundi, Ghana, Benin and Malawi. The main features of these operations are (KIT, 1987):

1 The product can only become an acceptable alternative to home preparation if the selling price is not higher than 2-3 $\times$ lci.

2 The scale of operations should be sufficiently large to support the cost of hygienic processing facilities and labour wages; on the other hand, it is limited by the market demand, costs of transport of raw materials and final product, and capacity of storage facilities. In semi-urban surroundings, daily production of $100-200 \mathrm{~kg}$ finished product by $3-5$ persons is regarded as feasible.

3 Ingredient long-term storage capacity is part of the operation. It enables the purchase of ingredients (at the lowest price $=1 \times$ lci) for 60 per cent or more of a year's production capacity.

4 A simple dry process (Table 11.2), involving cleaning, roasting, dehusking, mixing, grinding and packaging, results in a sales price of $2-3 \times$ lci.

The packaged dry mix should be cooked into a semi-liquid porridge at home. Due to constraints of time, cooking is often carried out only once or twice a day. Since the infants require more frequent feeding, e.g. 3-5 times daily, porridge is left over for the next feeding time. Under the prevailing conditions of poor hygiene and lack of refrigerated storage, explosive growth of contaminating micro-organisms takes place. Such microbial activity may easily cause gastroenteritis with acute diarrhoea.

The above example illustrates the health risk associated with conventional weaning food prepared and handled under primitive conditions. At the Agricultural University of Wageningen, a method to improve the microbiological safety of cooked porridges was developed. It is based on a simple fermentation system, which can be carried out with only a few vessels, without requiring sterile conditions or pure starter cultures (Nout et al., 1989b). Fermentation is a traditionally known and accepted processing technique in Africa. Souring by lactic acid bacteria lowers the $\mathrm{pH}$ of the final product, and has been shown to protect it from proliferation of contaminating intestinal bacteria (Nout et al., 1989a). In addition, digestibility of nitrogen compounds and bio-availability of minerals of the porridge are improved (Lorri and Svanberg, 1988; Svanberg and Lorri, 1988). In addition, oligosaccharides from pulses which are responsible for flatulence and 'loose stools' are reduced through fermentation.

For the purpose of fermentation, a wet process (Table 11.2) is required, involving cleaning, dehusking, mixing, coarse grinding, moistening, fermentation, dehydration, fine grinding and packaging. This process at $200 \mathrm{~kg} /$ day is $20-40$ per cent more expensive than the dry process. It also takes more processing time and involves more process operations. Present investigations aim at quantifying the nutritional benefits of the wet process; if these compensate for the higher cost involved, the total of hygienic and nutritional advantages render it a promising technique for future field testing. The successful introduction and adoption of these techniques and subsequent consumption of the product would be expected to have a favourable impact on nutrition and health. Whether rural women will be willing and able to purchase these locally-produced weaning foods will depend, inter alia, on their awareness of their availability and advantages, the strength of competing demands on their limited income, and on the value (in its next best alternative use) of time saved in the home-preparation of weaning foods.

\section{Oil and Seed Processing}

For the processing of oil seeds into vegetable oil, technologies for various scales of processing are available. A choice, therefore, needs to be made as to 'appropriateness' in each situation, given the social, cultural and economic environment and the priority development objectives. Processing can be done at large-scale (exceeding 1 tonne/hour) through expelling or solvent extraction. For medium- 
Table 11.2 Weaning food process options. Scale of production approx. $200 \mathrm{~kg} / \mathrm{day}$

\begin{tabular}{|c|c|}
\hline Dry process & Wet process \\
\hline \multicolumn{2}{|c|}{$\begin{array}{c}\text { Ingredients (cereals, pulses) } \\
\text { Cleaning } \\
\end{array}$} \\
\hline $\begin{array}{l}\text { Roasting } 230^{\circ} \mathrm{C}, 3-8 \mathrm{~min} \text {. } \\
\downarrow \\
\text { Dehusking } \\
\downarrow \\
\text { Mixing } \\
\downarrow \\
\text { Coarse grinding } \\
\downarrow \\
\text { Fine grinding } \\
\text { Packaging }\end{array}$ & $\begin{array}{c}\text { Dehusking } \\
\downarrow \\
\text { Mixing } \\
\downarrow \\
\text { Coarse grinding } \\
\downarrow \\
\text { Moistening } \\
\downarrow \\
\text { Fermentation } \\
12-18 \text { hours } \\
\text { at } 25-30^{\circ} \mathrm{C} \\
\downarrow \\
\text { Dehydration } \\
\downarrow \\
\text { Fine grinding } \\
\downarrow \\
\text { Packaging }\end{array}$ \\
\hline 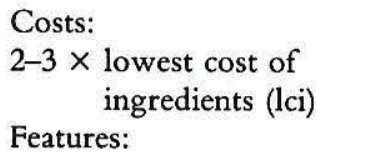 & $3-4 \times 1 \mathrm{ci}$ \\
\hline Simple and fast process & $\begin{array}{l}\text { Slower and more complex } \\
\text { Microbiological safety } \\
\text { Promising nutritional } \\
\text { benefits }\end{array}$ \\
\hline
\end{tabular}

(100-1,000 kg/hour) and small-scale processing (10-100 kg/hour) both expelling and pressing are commonly-used techniques. A problem of expellers is their wear and tear, which necessitates regular supply of spare expeller screws or repair by welding with a very hard alloy. Oil pressing is carried out using.hydraulic presses fitted with larger industrial jacks or even a simple lorry jack. Both these technologies have been tried out at village level. Since 1982, a project has been set up in Mali to develop and disseminate a system for processing shea nuts that improves on the traditional system. For this project, an oven, a hydraulic hand press and a cake-expel stand have been developed by KIT. After introductory tests, the local production of the equipment has been set up and the equipment is being disseminated.

Oil cannot be extracted from seeds in one single operation; the process consists of several stages. In Figure 11.2, the traditional (wet) process is compared with an improved small-scale 'dry' process. Size reduction to open up the cell structure, and moistening and heating are crucial to obtain a good oil recovery. The 'dry' process employs the manual hydraulic press and is an interesting option for women because:

1 The extended heating of kernels in a traditional oven can be omitted, thus saving firewood and time.

2 Work is faster and lighter because the mass is easier to pound.

3 Little water is required, which saves work.

4 Oil recovery, which of course depends on the quality of the kernels, is higher, i.e. 38.5 per cent average yield against 25 per cent in the traditional process, that is about 75 per cent against respectively 50 per cent of total fat available in the kernels.

5 The cake, which is usually discarded, can be used as fuel.

This process is likely to be technically and culturally acceptable to women, because the crucial steps, such as 'size reduction' and 'cooking', are still carried out in the traditional way, by pounding and a pot over a fire, respectively. Learning from the experiences with shea butter production, the design has been improved to prevent rapid wear of parts of the jack pump and reinforce the frame. Notwithstanding the negative experiences that called for the improvements, the demand for shea nut presses is steadily increasing. By early 1987 the processing equipment had been installed in thirty-five villages in Mali. In addition, enquiries from neighbouring countries are increasing (Wiemer and Korthals-Altes, 1989). The small-scale expeller and hydraulic press are still too large in some village situations, and require too large an investment. For these reasons, the 'scissor jack press' and the low cost 'Ram press' were developed and are being tested in Tanzania (ATI, 1989).

A system for low-cost, small-scale, oil palm bunch processing was developed in Ghana by Kramer from the 'service mill' concept (Blaak, 1989). The joint processing by farmers and mill owner minimises the potential labour displacement and loss of control effects, and maximises the profits of small-scale producers, many of them women. The owner provides a fast-running digester, 

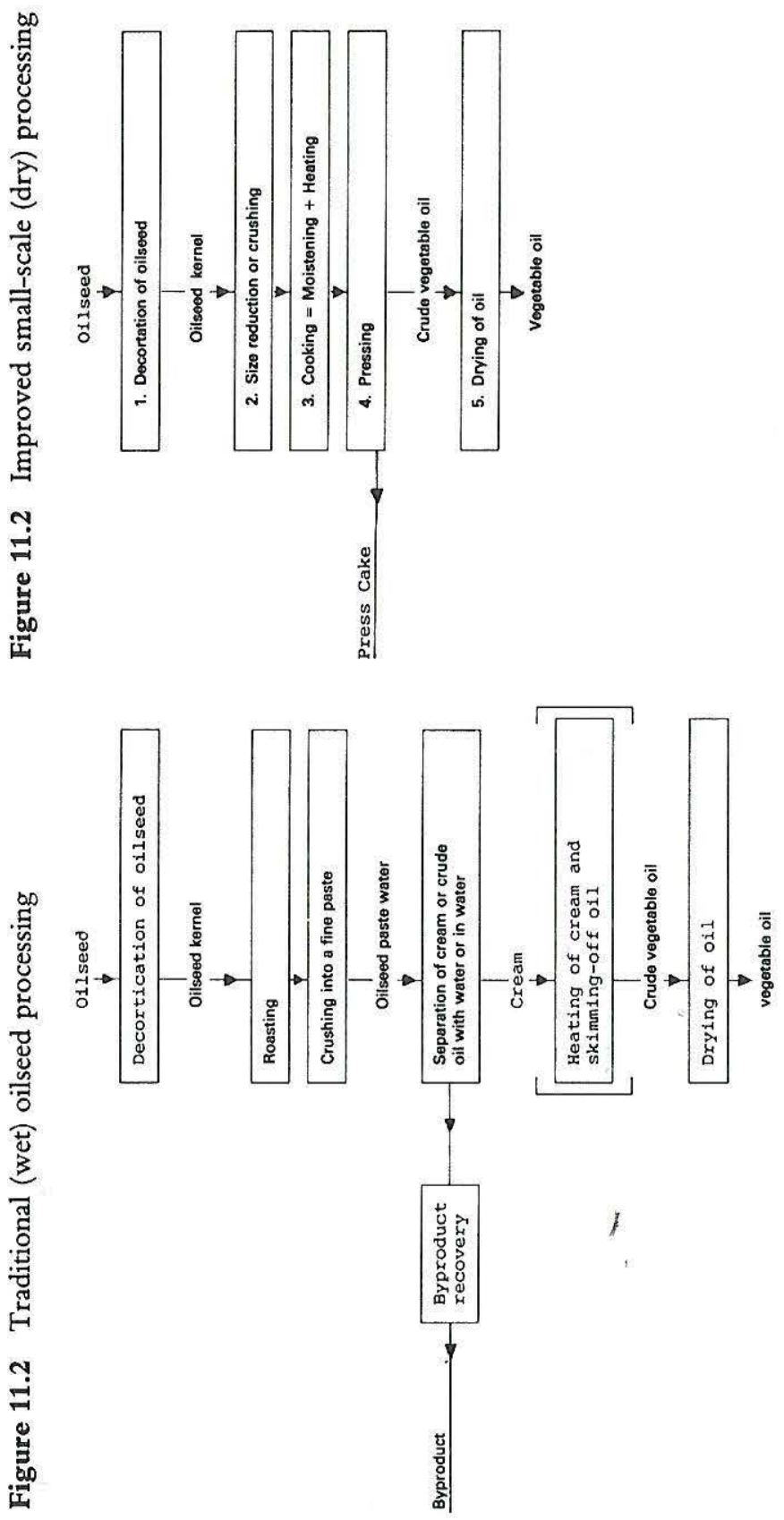

manually-operated hydraulic presses and a few operators. The farmers are responsible for bunch stripping, fruit cooking, transport of hot fruit to the digester, collection of the crude oil from the press and clarification of the oil, nut removal from the press cake, fermentation of the presscake and second pressing of the presscake. Milling charges are kept low (as the need for stocks and substantial working capital is eliminated), the identity of the fruit is maintained throughout the process, and a farmer planting higher-yielding tenera palms and harvesting at the correct ripeness receives the full benefit of her/his work. The Kramer mill employs eight persons per mill and has an oil to bunch extraction rate of only 2-3 per cent below the extraction rate of a high technology mill. Despite the presence of two high-technology mills, there are now twelve Kramer-type mills operating the Kade region, using locally-made equipment. The method allows considerable rural employment and provides a normal labourer's income to the numerous women who do most of the processing. In some areas, however, the crop density is too low to justify the establishment of even a Kramer mill, so ITA (International Technical Assistance) in the Netherlands are investigating the feasibility of a mobile mill.

\section{Root Crop Processing}

Cassava is the most important of the root and tuber crops in sub-Saharan Africa and it is widely processed both for home consumption and for sale. Cassava is the highest carbohydrate source per area, except for sugarcane, which makes it a particularly important crop given the decline in area of arable land available per person in rural areas. Per capita consumption of cassava in subSaharan Africa averages $118 \mathrm{~kg} /$ year, with a wide variation from $20 \mathrm{~kg} /$ year in low-consumption countries to over $400 \mathrm{~kg} /$ year in high-consumption countries (Hahn, 1988).

In West Africa, the market demand for cereals is growing more rapidly than the demand for cassava and other root and tubers. Probably this stems from the limited supply of cassava in urban areas, caused by marketing difficulties because of the poor keeping qualities of fresh cassava roots, and the availability of relative cheap, imported cereals (Delgado and Miller, 1985). FAO data suggest an increase in per capita consumption in parts of East Africa and highland Africa (Hahn, 1988). Bitter varieties enjoy increasing popularity with farmers since they are more resistant against field and storage pest and conditions of drought. The processing of these 
bitter varieties of cassava is critical. Whereas sweet cassava can be consumed fresh or be simply cooked, the bitter varieties need to be processed to remove naturally occurring toxic components. Toxicity in cassava is caused by the poison cyanide. Toxic effects occur when cyanide is liberated from a more complex chemical compound linamarin. The human body is able to detoxify the poison to a certain extent, but this goes at the expense of sulphur-containing proteins. If the diet contains sufficient protein, the body can withstand moderate quantities of cyanide. However, because of the very low protein content of cassava, accumulation of cyanide may occur with poor people having inadequate supply of protein-rich supplementary food. Both endemic goiter and cretinism can be aggravated by continuous dietary cyanide exposure from insufficiently processed cassava. The disorder konzo, a spastic paralysis of the legs, has also been associated with eating inadequately processed cassava and lack of protein-rich food (Rosling, 1987). These food-borne disorders have been recently reported in Zaire, Uganda, Tanzania and Mozambique. In Uganda and Mozambique it appears that the bitter varieties have been adopted by farmers before they had learned how to process the tubers properly so as to reduce the cyanide content. After having experienced the toxic effects of bitter cassava, the farming population starts experimenting with alternative processing methods, thereby often adopting the methods that are used in the area where the bitter variety came from. Likewise, cassava may be insufficiently processed during famine situations, because of lack of time to carry out the sometimes long detoxification methods. International research efforts have only recently focused on the effects of processing on the reduction of cyanide in cassava. Studies are now in progress to assess the fate of cyanide during the changeover from traditional methods of processing, their efficiency in detoxification, and the biochemical processes involved. The aim is to identify time-saving detoxification methods (Essers, 1989) for rural introduction.

Many products can be made from cassava, including fermented products such as gari, cassava flour for breadimaking, cassava starch, as well as chips and pellets for animal feed. Each product can be made using different scales of production from household to industrial level and with a variety of equipment (Bruinsma et al., 1983), and the choices and issues involved are illustrated here with reference to gari production. Gari is a popular convenience staple food in West Africa, but similar products are known elsewhere, e.g. farinha de mandioca in Brazil, and farinha torrada or rala in parts of Mozambique. The gari-making process consist basically of washing the tubers, peeling and grating, followed by fermentation during a few days. This fermentation takes place under pressure to squeeze out part of the moisture. The final step is a combined drying and frying operation aimed at preserving the product and pregelatinisation or precooking of the coarse flour.

Bruinsma et al. (1983) compared three scales of gari-processing operations (small-, medium- and large-scale), producing gari at approximately $2.2 \mathrm{~kg} /$ woman-hour, $70 \mathrm{~kg} /$ (wo)man hour and 450 $\mathrm{kg} /$ hour respectively. The fully mechanised process is inappropriate, given the needs, resources and management capability of a rural community. It needs a high level of investment, a well-organised supply of roots requiring one or more plantations, it employs relatively few people, it needs skilled labour and it has high costs of services (water, energy). Improvements in the traditional process (see Figure 11.3) would be much more likely to result in maintained (female) employment levels, increased labour productivity and increased output of gari. Generally, the first operation to be mechanised is grating. One hour mechanical grating saves 21 women working hours and is not as harmful to the hands as manual grating (Hahn, 1988). Mechanical graters are very useful but too expensive to be used at the village (less than 1,000 inhabitants), or single household level. Simple diesel-powered graters with a capacity of approximately $200 \mathrm{~kg}$ roots per hour can be mounted on a lorry, however. In this way, they can serve the countryside village 'factories' profitably, but have the disadvantage that they are owned and operated by men; this may imply negative consequences for the female labour force. It has been noted that where a more capital-intensive technology is introduced, men take advantage of the business opportunities it presents, and women tend to lose out (Burne, 1988). However, this is not an automatic consequence. A study of fifteen small-scale gari-making firms in the Brong Agafo region of Ghana illustrates the positive impact of small-scale business on the generation of employment, whether part-time, seasonal or full-time. Women entrepreneurs increased their output and incomes using inexpensive low-technology equipment; the only mechanised process was cassava grating, which was done at a service mill in the town owned and operated by men (White, 1985).

Women entrepreneurs have a potentially stronger position when they are organised in thein $~-w n$ groups or cooperatives. This gives them better access to credit and extension advice and a better position from which to negotiate marketing contracts and to introduce new products. These co-operatives can provide a basis from which women gain control and ownership of mechanised food- 


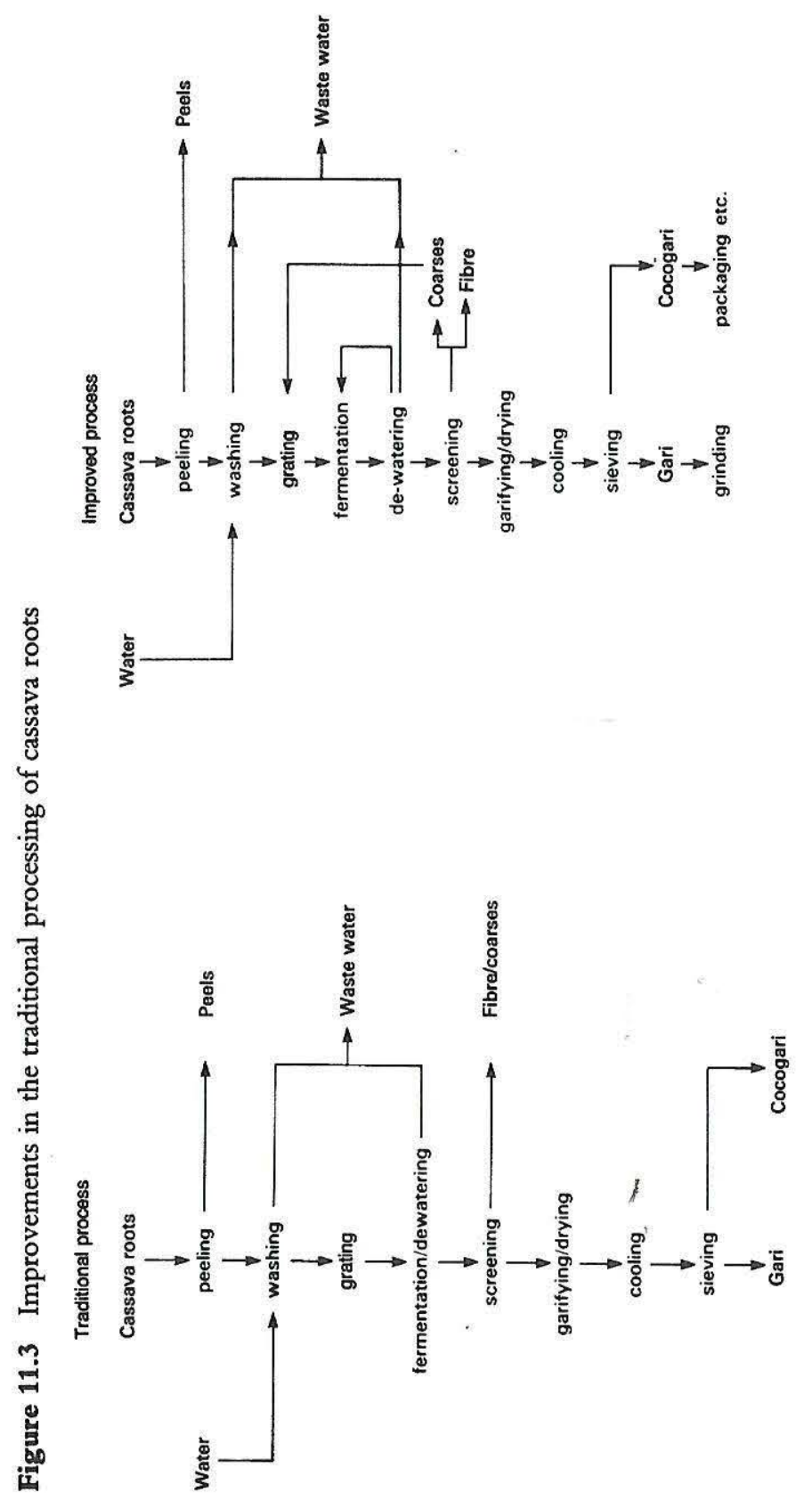

processing technology. This is occurring in Ghana where a women's co-operative, heavily supported through an FAO People Participation Project, began producing and selling gari. Using a modified traditional technique, a communal 'roasting shed', and through joint bulk purchasing of raw cassava, the fifteen women accumulated savings and were able to obtain the necessary credit to purchase a locallymade, gasoline-powered, cassava grating machine. The project provided intensive training in accounting and business management, and the volume of gari produced by members continues to expand. There are signs, however, that the management capacity of the group is nearing its limit. The long-term success of the enterprise will depend on how well its members solve future business crises. This cooperative gari-processing enterprise has already made a positive impact. Other villagers have been motivated to undertake gari processing, women members of the co-operative are much more confident and there are visible signs that their living standards have improved (housing improvements, more children at school, eating a better, more varied diet). There are now two fully-employed gari grater operators in the village, the women have plans to use the cassava peel to feed pigs, and people making sieves for the gari makers have a booming business (Nyarko-Fofie, 1989).

Initiatives are also being implemented at national level. The UNICEF/IITA Collaborative Program For Household Food Security and Nutrition took the initiative to set up Rural Cassava Processing and Utilisation Centres in Nigeria to promote the production of new and better quality cassava products, demonstrate new ways of cassava utilisation and seek a successful mode of management for the centres (Kwatia, 1986).

\section{Stimulation of Food Processing for Rural Development}

Strategies to stimulate the adoption of improved food processing technologies require, first, that their goal is clearly articulated. The priority needs, the desired impact and the intended beneficiaries must all be explicitly identified, as these determine the choice and scale of technology, which in turn will have to be supported by government policies, institutions and infrastructure.

Socio-economic Factors Influencing Transferability and Choice of Scale

Food-processing technologies, which have proved to be successful in the situations for which they were developed, may not be easily 
transferable. Experience shows that successful introduction and adoption depend on a variety of socio-economic factors, as well as on technical appropriateness and financial viability. Technological innovation is a form of social change; acceptance depends not only on efficiency of hardware and economic soundness, but also on the degree of socio-cultural resistance (ILO, 1984). The following list of socio-economic factors is not meant to be complete, but only illustrative of some of these issues:

1 Traditional work and co-operative systems.

2 Entrepreneurship and ownership.

3 Demand for products and product quality.

4 Economies of scale.

5 Objectives.

Knowledge of traditional work habits and co-operation systems is essential in the selection and adaptation of technology aimed at saving women's labour-time. The most important processes in this respect are those of cereal dehulling and milling, and production of vegetable oil. In projects on cereal milling, women's needs and working habits are often not sufficiently known or taken into consideration in the development and introduction of new technologies. It is the experience of various projects that the closer a new technology is to current practice, and the greater the ease with which the 'new' methods can be mastered by the available skill, the greater is the likelihood that sustained use will be made of the 'new' technology. A multidisciplinary framework for analysing the effects and impact on women of technological change in food processing (ILO, 1984), and based on field work in Ghana, Sierra Leone and Kenya, assessed the importance of a range of both technical factors (e.g. auxiliary input requirements such as water and fuel, potential use of by-products), and socio-cultural factors (e.g. similarity to traditional tasks) in technology transfer. The study concluded that successful adoption is more likely when women have control over the increased income accruing, when the introduced technology does not disrupt concurrent domestic work and child-care arrangements, and when it is close to the source of raw materials.

When women's food-processing activities are mechanised and commercialised, they are frequently taken over by men. In Nigeria, mechanisation (especially at the industrial level) has been associated with the displacement of women from traditional productive activities (Ladipo and Ade Alao, 1984), in favour of men who own and operate the grating and dewatering machines used in gari processing (Williams, 1981). Female labour displacement resulting from the introduction of food-processing technology is reduced when the users of the technology maintain control (and ownership) over their product. Both custom hire arrangements and service mills have proved positive in this respect, as have the joint processing arrangements in Ghana (Kramer mills) which maintain the farmers' interest in the oil and enable her/him to realise a larger share of the value-added.

Greater benefits are expected to accrue to those who own and control the technology itself, and initiatives to promote and support women's co-operatives are being directed towards this end. However, it is often difficult to establish an adequate organisational structure enabling women to manage mechanical mills and to ensure the maintenance, repair and supply of spare parts (Ballot, 1985). In the introduction of labour-saving technology in the processing of oil seeds, related problems are encountered with regard to selection of an appropriate organisation structure for women's groups to manage a hydraulic press. Often the available small-scale equipment still has a too high capacity to be used profitably by groups of women, who co-operate by experience easily. The group of women, necessary to make a hydraulic press a profitable operation, is larger and thus there is a need to introduce new collaboration structures. Technological development work on the equipment for oil production is however still going on (Wiemer and Korthals-Altes, 1989). Successful business management of mechanical equipment requires a variety of entrepreneurial skills, and co-operative ownership of oil processing mills in West Africa has not worked well because of the scope for corruption (Blaak, 1989). Burne (1988) concludes that if the beneficiaries cannot own and control the improvements you are introducing, individually or at least collectively, then the benefits have to be pretty good to outweigh their losses of economic freedom and self-reliance. This brings us to the factor of entrepreneurship, which is very important in the management of processing activities. It demands specific skills to keep the equipment operating at an economic level, organise maintenance and repair, and the supply of spare parts.

The adoption of food-processing technology and the resulting impact are influenced (and possibly constrained) by the level of demand for the processed product, and also for its by-products. Demand depends on the product's price, the price and availability of substitutes, consumer tastes and preferences, factors like ease of preparation, similarity to traditionally processed products, and of 
course, disposable income. In some parts of Africa, the preference is for more full-flavoured, darker coloured oil made from wild palms or groundnuts in the traditional ways, rather than for the refined cooking oil (Blaak, 1989; Machell, 1989). In contrast, advertising campaigns and ease of preparation considerations have increased the demand for refined flours made from imported grain. (ILO, 1984; Delgado and Miller, 1985). Although market research has not usually been part of the food technology development process in Africa, it clearly has a major role to play in defining appropriate food processing activities.

The fact that economies of scale play an important role in the profitability of a technology is well known. However, for certain processes intermediate levels of technologies are either scarce or not available. So there is little scope for profiting from economies of scale. For instance, in oilseed processing, traditional family-level processing is profitable because the opportunity cost of labour in the off-season is very low and equipment used is simple. The use of medium-scale hydraulic presses mentioned earlier, requires much organisation and co-operative processing in order to be costeffective. The next step is often the large-scale processing factory operating at a higher efficiency. Medium-scale processing facilities operating as service mills are still scarce in sub-Saharan Africa. In addition to the competition of large-scale oil mills, medium-scale units must compete with cheap oil bought on the market through food aid programmes. Blaak's study of labour-intensive, smallscale oil palm pressing in Ghana refutes the assumption frequently made that the larger the scale, the lower the per unit production cost (Blaak, 1989). Larger-scale equipment is very costly; the main costs being interest on and depreciation of capital. In sub-Saharan Africa, labour costs are relatively low, which gives an economic advantage to labour-intensive systems of production and organisation.

Unfortunately, development agencies often work in ignorance of what their colleague organisations are up to. Sometimes this causes economic mishaps such as disturbance of local niarket prices; on other occasions, technological standardisation and exchange of know-how have been frustrated by uncoordinated dumpings of a confusing variety of brands, types and sizes of machinery with different origins and instructions. Frequently, the aims of separate programmes diverge and their objectives conflict. Even within the same project, conflicting objectives are formulated. Sometimes a project for food processing aims at the same time to supply income for rural women; process existing surpluses such as seasonal sur- pluses of fruit and vegetables; improve nutrition; respond to a named demand by consumers; and substitute imports. Of course, these aims cannot always be met all at the same time. Likewise, in projects introducing cereal mills the alleviation of women's work and the generation of income are conflicting. The costs of grinding cereals should be as low as possible to serve many women, thereby satisfying the primary objective. However, with a low price per $\mathrm{kg}$ it is impossible to create large wage benefits. This is the case where the target beneficiaries have not been clearly identified. Are they the rural women, the mill owners and employees, or the consumers of the processed product? It has already been stressed that the choice of a 'new' food processing technology, both of scale and of hardware, needs to be consonant with the broader development objectives of governments.

In an attempt to approach the problem of selection of technology in a systematic way, the decision scheme presented in Figure 11.4 was developed. The factors mentioned above are to be included in the criteria that determine the selection. As the figure shows, the entire selection procedure should be followed in close consultation with the target group. A final example illustrates the dangers of not doing so.

Traditionally, the production of palm oil in oil palm- and cocoagrowing areas in Nigeria is a quite labour-intensive process and results in a low rate of extraction. The men harvest the fruit, and the women crack the kernels and process the oil. The oil yield of this traditional process is only $40-50$ per cent of the oil available in the fruit. Pressing the hot pulp in two stages with a hydraulic press may increase the yield to 90 per cent. The potential increase in oil yield and the necessity of diversifying agricultural production in an area prompted the Ministry of Agriculture in Nigeria to introduce the hydraulic press to a village called Gbebun. However, some women never used the press, and others stopped using it after some time, mainly because the by-products contained less oil and therefore their fuel quality was lower, and the increased oil production belonged to the men (Obibuaku, 1967). One could learn from this case-study that, although meetings were held and ideas exchanged, the villagers did not get enough time to think about what the proposed technology would mean to them. The role of the women in the traditional process was not fully recognised, and they were not sufficiently involved in choosing the technology and introducing it. 


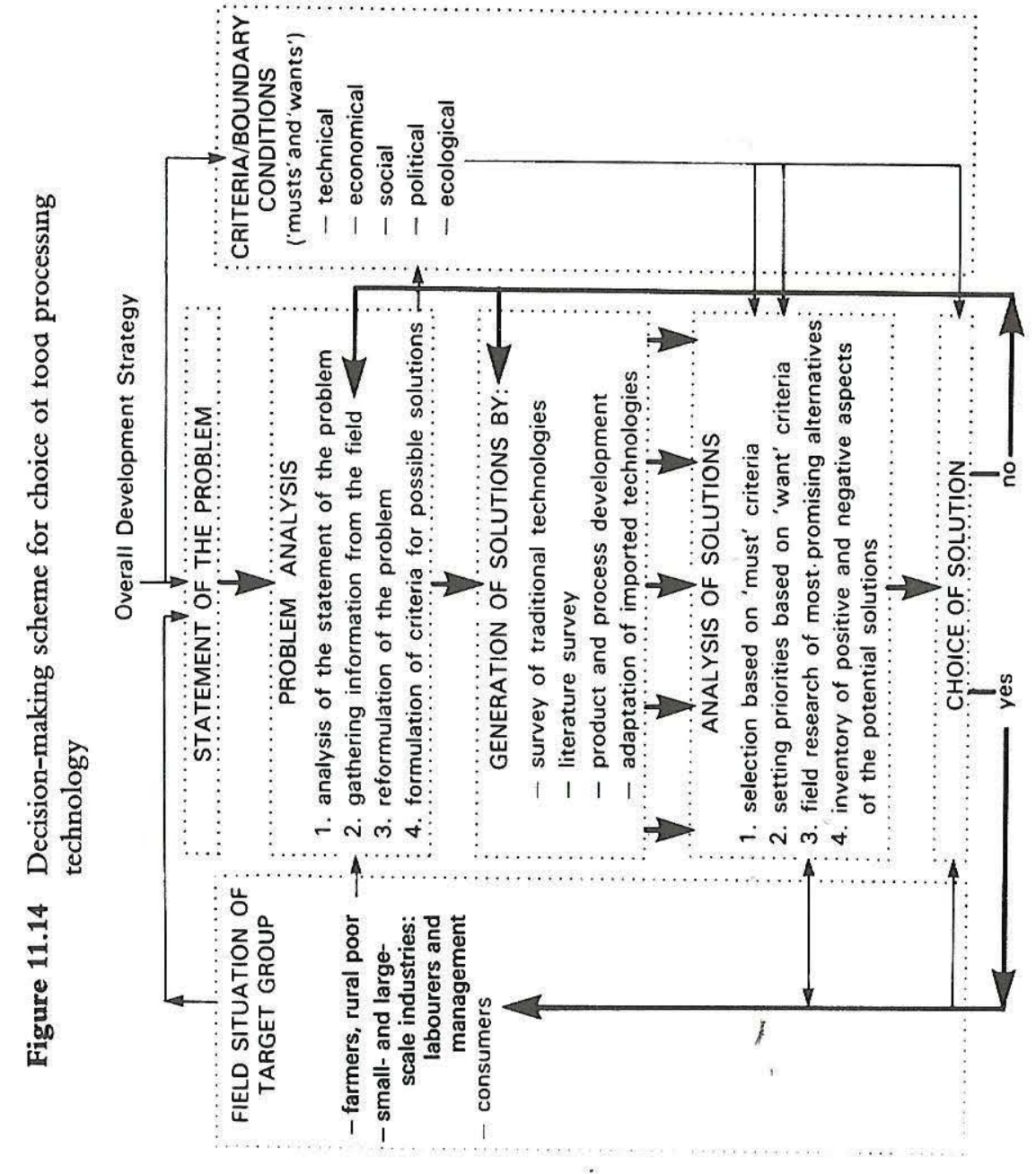

\section{Potential Impact of Food-Processing Technology}

The impact of food-processing technology on women may be positive when they are released from the time-consuming and arduous work of processing food by hand, and are thus able to spend more time on food or cash-crop production, on other income-earning activities, caring for children or resting. However, when food processing is mechanised, women may have to spend time and effort head-loading their grain to the mill, wage labourers may lose their means of livelihood, the value-added in food processing may accrue disproportionately to the owners and operators of the technology who are usually men, and shortages in raw materials may be exacerbated.

The longer-term impact depends on sustainability: whether the technology continues effectively and efficiently or falls into disuse when diesel or spare parts become unavailable; whether the ownership/management arrangements are sustainable: whether existing government policies (price ratios, import prices, etc.) continue and the profitability of the processing operation is maintained. The viability of women's co-operative groups as technology and business-managers, and of small-scale rural enterprise generally, depends on continued support to local technology units and centres for research and development work and help in building an indigenous technological capacity.

But alongside the recommendations, the question still remains: Is there sufficient evidence that small-scale food-processing technology is more likely to have the intended impacts than medium- or large-scale activities?

\section{Acknowledgement}

The authors wish to thank Louise Bevan, Sander Essers, Theo van de Sande and Willem Würdemann for their interest and helpful comments. 


\section{References}

ATI, 'Sunflower Seed Oil Processing in Tanzania', Appropriate Technology International Bulletin no. 17, 1989

Ballot, J., Food Systems and Society: The situation of women in the equatoria region, Sudan, Report on a Mission, Working Paper 1. UN Research Institute For Social Development, 1985

Blaak, G., 'New Concepts in Low-cost Small-scale Oil Palm Bunch Processing in West Africa', Paper submitted at the International Conference on Palms and Palm Products, Nigerian Institute for Oil Palm Research, November 1989

Bruinsma, D. H., Witsenburg, W. W. and Würdemann, W., Selection of Technology for Food Processing in Developing Countries, Wageningen, Pudoc, 1983

Burne, S., 'Food Processing Calls for the First Steps in Technology', Ceres, FAO, 21, 4, 1988

Delgado, C. L. and Miller, C. P. J., 'Changing Food Patterns in West Africa. Implications for policy research', Food Policy, 10, 1, 1985

Essers, A. J. A., 'Detoxification of Cassava at Household Level in Rural Africa', Project proposal, Wageningen, Agricultural University, Dept of Food Science, 1989

Hahn, N. D., 'Cassava Production/Utilization and Social Change, The role of cassaya in bringing positive change to African households', International Society for Tropical Root Crops Symposium, 30 October5 November Bangkok, 1988

Hyman, E. L., 'The Importance of Small and Micro-enterprises in Rural Areas of Africa', Paper for the Expert Consultation on Small Rural Enterprises in Africa, FAO, Rome, 11-15 December 1989

ILO, 'Technological Change, Basic Needs and the Condition of Women', Report of the Joint ILO Government of Norway Africa Regional Project, ILO/NOR/78/RAF/27, Geneva, 1984.

—, Small-scale Maize Milling, Technical memorandum no. 7, Technology Series, second impression, Geneva, 1987

KIT, Weaning Food, A new approach to small-scale weaning food production from indigenous raw materials in tropical countries, Amsterdam, Royal Tropical Institute, 1988

Kwatia, J. T., Report on the Existing Cassava Storage and Processing Technologies in Southern Nigeria with a View of Making Recommendations for the Establishment of Rural Cassava Processing and Utilization Centers. Ibadan, Nigeria Spectrum Books, 1986

Ladipo, P. A. and Ade Alao, J., 'Mechanization of Food Processing, A Study of Women's Needs', in Women's Contributions to Food Production and Rural Development in Africa, Proceedings of a Workshop, AAASA, Addis Ababa, 1984

Lorri, W. S. M. and Svanberg, U., 'Improved Protein Digestibility in 248
Cereal-based Weaning Foods by Lactic Acid Fermentation', Paper presented at the Third Africa Food and Nutrition Congress, Harare, Zimbabwe, 5-8 September 1988

Machell, K., 'The Introduction of Edible Oil Processing in a Southern African Country', Paper for the Expert Consultation on Small Rural Enterprises in Africa, FAO, Rome, 11-15 December 1989

Nout, M. J. R., Rombouts, F. M. and Havelaar, A., 'Effect of Accelerated Natural Lactic Fermentation of Infant Food Ingredients on Some Pathogenic Micro-organisms', Int. Joumal of Food Microbiology 8, 1989a, pp. $351-61$

-, Rombouts, F. M. and Hautvast, J. G. A. J., 'Accelerated Natural Lactic Fermentation of Infant Food Formulations', UNU Food and Nutrition Bulletin 11 (1) 1989b, pp. 65-73

Nyarko-Fofie, T., 'Small Enterprise Management Development - Subinso no. 1 "Gari" Processing Group - A case study', Paper submitted to Expert Consultation on Small Rural Enterprises in Africa, FAO, Rome, 11-15 December 1989

Obibuaku, L. O., 'Socio-economic Problems in the Adoption Process: Introduction of a hydraulic palm-oil press', Rural Sociology, 32, 4, 1967

Rosling, H., 'Cassava Toxicity and Food Security. A review of health effects of cyanide exposure from cassava and of ways to prevent these effects', IITA-UNICEF Programme on Household Food Security and Nutrition, 1987

Schmidt, O. G., 'The Place of Dehulling in African Sorghum and Millet Food Systems', Annual Meeting, GASCA, Munich, 1987

- . 'The Sorghum Dehuller - a case study in innovation', in Marilyn Carr (ed.), Sustainable Industrial Development, London, IT Publications, 1988

Svanberg, U. and Lorri, W. S. M., 'Improved Iron Availability in Weaning Foods using Germination and Fermentation', Paper presented at the Third Africa Food and Nutrition Congress, Harare, Zimbabwe, 5-8 September 1988

White, S., 'African Women as Small-scale Entrepreneurs: Their impact on employment creation', in J. Monson and M. Kalb (eds), Women as Food Producers in Developing Countries, University of California, 1985

Wiemer, H. J. and Korthals-Altes, F. W., Small-scale Processing of Oil Fruits and Oil Seeds, Braunschweig, Vieweg, 1989

Williams, C. E., 'The Effect of Technological Innovation among Rural Women in Nigeria: A case study of "gari" processing in selected villages of Bendel State of Nigeria', in Women's Contributions to Food Production and Rural Development in Africa, Proceedings of a Workshop, AAASA, Addis Ababa, 1984 